\title{
Getting to the Emergency Department in Time: Interviews With Patients and Their Caregivers on the Challenges to Emergency Care Utilization in Rural Uganda - a Grounded Theory Approach
}

\author{
Getting it to the ED in Time: Interviews on Challenges to Emergency Care \\ Utilization in Rural Uganda
}

Ashley E. Pickering ${ }^{1,2 \mathbb{I}^{*}}$, Heather M. Dreifuss ${ }^{3 \pi}$, Charles Ndyamwijuka ${ }^{2 \pi}$, Mark Nichter, ${ }^{4,5 \pi}$, Bradley A. Dreifuss $2,5,6 \pi$, on behalf of the Global Emergency Care Collaborative Investigators

1. Department of Emergency Medicine, University of Maryland Medical Center, Baltimore,

$$
\text { MD, USA }
$$

2. Global Emergency Care, Shrewsbury, MA, USA

3. Department of Health Sciences, Northern Arizona University, Flagstaff, AZ, USA

4. School of Anthropology, University of Arizona, Tucson, AZ, USA

5. Mel and Enid Zuckerman College of Public Health, University of Arizona, Tucson, AZ, USA

6. Department of Emergency Medicine, College of Medicine, University of Arizona, Tucson, AZ, USA

* Corresponding Author

Email: AshleyPickering@gmail.com 
medRxiv preprint doi: https://doi.org/10.1101/2021.09.30.21264131; this version posted October 2, 2021. The copyright holder for this preprint (which was not certified by peer review) is the author/funder, who has granted medRxiv a license to display the preprint in perpetuity. It is made available under a CC-BY-NC-ND 4.0 International license .

${ }^{\text {II }}$ These authors contributed equally to this work

Membership of the Global Emergency Care Collaborative Investigators is provided in the Acknowledgments 


\section{Abstract}

\section{Objectives}

3 Karoli Lwanga Hospital and Global Emergency Care, a 501(c)(3) nongovernmental

4 organization, operate an Emergency Department (ED) in Uganda's rural Rukungiri District.

5 Despite available emergency care (EC), preventable death and disability persist due to delayed

6 patient presentations. Implementation of effective EC requires assessment of socioeconomic,

7 cultural, and structural factors leading to treatment delay.

\section{Methods}

9 We purposefully sampled and interviewed patients and caregivers presenting to the ED

10 more than 12 hours after onset of chief complaint in January-March 2017 to include various

11 ages, genders, and complaints. Semistructured interviews addressing actions taken before

12 seeking EC and delays to presentation once the need for EC was recognized were conducted.

13 Interviews were audio recorded, translated, and transcribed, enabling the interdisciplinary and

14 multicultural research team to conduct thematic analysis utilizing a grounded theory approach.

\section{Results}

16 The 50 ED patients for whom care was sought (mean age 33) had approximately even

17 distribution of gender, as well as occupation (none, subsistence farmers and small business

18 owner). Interviews were conducted with 37 caregivers and 13 ED patients. The majority of

19 interviewees (mean age 38 years) were women with a primary education. The median duration of

20 patients' chief complaint on ED presentation was 5.5 days. On average, participants identified

21 severe symptoms necessitating EC 1 day before presentation. Four themes of treatment delay 
medRxiv preprint doi: https://doi.org/10.1101/2021.09.30.21264131; this version posted October 2, 2021. The copyright holder for this preprint (which was not certified by peer review) is the author/funder, who has granted medRxiv a license to display the preprint in perpetuity.

It is made available under a CC-BY-NC-ND 4.0 International license .

22 before and after severity were recognized were identified: 1)_Cultural factors and limited

23 knowledge of emergency signs and initial actions to take_; 2) Use of local health facilities despite

24 perception of inadequate services; 3) Lack of resources to cover the anticipated cost of obtaining

25 EC; 4) Inadequate transportation options.

\section{Conclusions}

27 Interventions are warranted to address each of the four major reasons for treatment

28 delay. The next stage of formative research will generate intervention strategies and assess the

29 opportunities and challenges to implementation with community and health system stakeholders.

\section{Introduction}

In low- and middle-income countries (LMICs), 24 million lives are lost annually due to

32 emergency conditions that could be addressed through implementation of comprehensive

33 emergency care (EC) systems, with $21 \%$ of these deaths occurring in sub-Saharan Africa (SSA)

34 [1]. In 2007, the World Health Assembly resolution on EC systems encouraged health systems

35 research enabling the expansion of effective EC systems globally. More specifically, it urged

36 member states to identify the unmet needs of populations, institute formal EC systems, and

37 develop capacity as a means to reduce catastrophic morbidity and mortality [2]. In 2019, World

38 Health Assembly resolution 72.16 redoubled and expanded these calls to action, including

39 encouraging initiatives to increase awareness of, and expand management capacity for,

40 emergency situations at the community level [3]. Despite the recent establishment of academic

41 EC training and clinical care programs in SSA, there has been limited large-scale implementation

42 of community-based EC services.

43 Until recently, Uganda, like many LMICs lacked EC services. Efforts are under way to 
medRxiv preprint doi: https://doi.org/10.1101/2021.09.30.21264131; this version posted October 2, 2021. The copyright holder for this preprint (which was not certified by peer review) is the author/funder, who has granted medRxiv a license to display the preprint in perpetuity.

It is made available under a CC-BY-NC-ND 4.0 International license .

44 develop a well-coordinated EC system, train appropriate workforce to staff EC facilities, and

45 inform the community about new EC resources available. As part of these efforts, in 2008,

46 Global Emergency Care (GEC), a US-based 501(c)[3] nongovernmental organization, partnered

47 with Karoli Lwanga Hospital, known locally as Nyakibale, to build and staff rural Uganda's first

48 Emergency Department (ED) with nonrotating, formally trained staff. This ED provides high-

49 quality, timely care, evaluating and stabilizing patients before requiring payment. However,

50 patients often arrive at the ED late in the course of illness or injury, reducing the potential impact

51 of EC interventions.

52 Delays in utilization of available EC are widely recognized though not well understood,

53 ranking second among 7 priority research questions identified to facilitate the improvement of

54 EC in LMICs through a research priority setting exercise conducted by a multidisciplinary

55 coalition of researchers and stakeholders, the Global Emergency Care Research Network [4].

56 The global emergency medicine community recognizes the need for qualitative research to

57 better understand the perspectives and experiences of those seeking to utilize EC, as well as

58 assess the socioeconomic, cultural, and structural barriers leading to treatment delay [5]. Our

59 research goal was to better understand these barriers, particularly the challenges rural Ugandans

60 face in accessing and utilizing EC, by interviewing patients and caregivers in the ED.

\section{The Rukungiri District}

62 The Rukungiri District is located in rural Southwest Uganda. The district is mainly

63 farmland with one urban center. Dirt roads traverse steep, rocky hills [6]. There are 2 "rainy

64 seasons," when heavy rains render dirt roads barely passable for days. Motorcycle taxis are the

65 most prevalent mode of vehicular transportation, as they can navigate footpaths reaching homes 
medRxiv preprint doi: https://doi.org/10.1101/2021.09.30.21264131; this version posted October 2, 2021. The copyright holder for this preprint (which was not certified by peer review) is the author/funder, who has granted medRxiv a license to display the preprint in perpetuity.

It is made available under a CC-BY-NC-ND 4.0 International license .

66 and small villages. As of the last published district-level census in 2014, very few households

67 owned automobiles; 7\% of households owned motorcycles and 19\%, bicycles [7].

The vast majority of inhabitants are subsistence farmers (78\%), and most lack regular

69 access to money, especially between harvest seasons [6]. Most homes have no electricity [7]. In

70 2019, there were 57 mobile phone subscriptions per 100 Ugandans nationwide [8]. While mobile

71 phone ownership is increasing substantially, credit is typically purchased only as needed and

72 may not be available at the time of an emergency.

\section{The Ugandan Health Care System} comprising:

- "Traditional" and allopathic practitioners

- Private, nonprofit, and government health facilities

- Vendors selling medicines in small shops and local markets

80 Ugandans utilize traditional remedies [9-11]. In many small villages, private clinics and

81 pharmacies are often staffed by laypersons with no formal health care training. In major trading

82 centers, private clinics staffed by nurses, and possibly a physician, may have limited laboratory

83 and/or imaging capacity. The quality of care at private health facilities varies widely, and their

84 patients generally must pay out of pocket before receiving services.

85 The Ugandan government provides a multitiered health care system with the health

86 service infrastructure following a pattern of the country's administrative units, with health

87 centers (HCs) of increasing capacity (designated levels II-IV), general hospitals (formerly 
medRxiv preprint doi: https://doi.org/10.1101/2021.09.30.21264131; this version posted October 2, 2021. The copyright holder for this preprint (which was not certified by peer review) is the author/funder, who has granted medRxiv a license to display the preprint in perpetuity.

It is made available under a CC-BY-NC-ND 4.0 International license .

88 known as district hospitals), and regional referral hospitals. HC IIs are nurse-run clinics at the

89 village level, while larger facilities (HC III and IV) in trading centers are staffed by midlevel

90 providers, typically Clinical Officers with 2-3 years of medical training, and deliver primary care

91 and maternity services, with capacity to provide limited surgical, inpatient, laboratory, and blood

92 transfusion services [12,13]. User fees for government health care were abolished in 2001.

93 Following this, an initial decline in services and drug shortages increased the use of private

94 health care [14]. In 2017, when we conducted these interviews, there was no ambulance

95 available in the district.

96 Karoli Lwanga Hospital ED

97 Karoli Lwanga Hospital (Nyakibale) is a private not-for-profit district hospital. In 2008,

98 GEC partnered with the hospital to open the first fully functional ED in Uganda and a 2-year

99 Emergency Care Practitioner (ECP) training program for Ugandan nurses. The ECP program

100 was developed to address Uganda's chronic physician shortage (3 physicians per 100000

101 residents in the Rukungiri District as of 2015) and lack of specialty trained EC professionals [6].

102 The program's goal was to train ED-based nonphysician clinicians to triage, evaluate, stabilize,

103 and treat patients before admitting them to already-overburdened hospital wards, sending them

104 for surgery, or discharging them home. Unlike other Ugandan health care facilities, patients are

105 clinically stabilized prior to payment, and the ED treats any patient who presents [15]. However,

106 acuity is high, with ED patient mortality of $2.1 \%$ and an admission rate of $66.3 \%$ (2017,

107 unpublished data). Delayed ED presentation can reasonably be surmised to be among the

108 causative factors. 
medRxiv preprint doi: https://doi.org/10.1101/2021.09.30.21264131; this version posted October 2, 2021. The copyright holder for this preprint (which was not certified by peer review) is the author/funder, who has granted medRxiv a license to display the preprint in perpetuity.

It is made available under a CC-BY-NC-ND 4.0 International license .

109

110

111

112

113

114

115

116

117

118

119

120

121

122

124

125

126

127

128

129

130

131

\section{Methods}

Semistructured interviews with ED patients or their caregivers were conducted at Karoli

Lwanga Hospital. A purposeful sample of 50 patients arriving to the $E D \geq 12$ hours after onset of

the complaint that they sought care for (chief complaint (CC)) were interviewed between January

19 and March 29, 2017. The sample was selected to take into account age, gender, type and

severity of CC, as well as "information-rich cases," which we defined as individuals having

significant experience with challenges in EC access and utilization, based on conversations with

ED staff [16]. Further, as weather may influence delay, the interviews spanned dry and rainy

seasons. For patients with known chronic disease, we included in our sample only those with

acute presentations of the disease, rather than those simply seeking ongoing treatment related to

the disease. Patients or their caregiver were approached in person in the ED or hospital wards.

Recruitment and interviews did not interfere with patients' clinical care. The "caregiver"

accompanying the patient, was interviewed with pediatric patients and patients who could not be

interviewed directly because of illness or preference.

Research ethics approval was obtained through the University of Arizona Institutional

Review Board (Tucson), The AIDS Support Organization Research Ethics Committee (Kampala, Uganda), and the Ugandan National Council of Science and Technology (Kampala). Karoli

Lwanga Hospital leadership supported the study. Verbal informed consent was approved by the

organizations listed above due to low literacy rates in the community. It was obtained from all

participants, witnessed by the lead researcher (AP) and head research assistant (NC) and

documented on a verbal consent form with AP's signature. In the case of caregiver interviews,

assent was obtained from patients old enough, or alert enough to provide it. In most instances

this applied to the young children, the elderly and those with severe illness. 
medRxiv preprint doi: https://doi.org/10.1101/2021.09.30.21264131; this version posted October 2, 2021. The copyright holder for this preprint (which was not certified by peer review) is the author/funder, who has granted medRxiv a license to display the preprint in perpetuity.

It is made available under a CC-BY-NC-ND 4.0 International license .

133 actions taken before seeking EC and delays to presentation once the need for EC was recognized.

134 The interview guide was developed by AP (graduate training in public health, qualitative

135 methods and medical anthropology), BD (emergency medicine global health fellowship and

136 graduate training in public health), MN (Regents Professor of medical anthropology), and HD

137 (graduate training in public health and qualitative research experience) in consultation with

138 Ugandan members of the GEC Research Team. It was based on the guiding theory of the Three

139 Delays Model [17], described in depth in the Discussion, and on prior quantitative data regarding

140 barriers to ED utilization at Karoli Lwanga Hospital ED (unpublished). The interview guide

141 remained constant, with minor changes to wording throughout the 50 interviews. The lead

142 researcher (AP) and Ugandan members of the GEC Research Team translated the core questions

143 into the local dialects (Runyankore/Rukiga). Once consensus was reached in the phrasing of

144 questions, back-translation to English was undertaken. The English version is provided as

145 Appendix S1.

146 After training in qualitative interview-based research methods by AP, the head research

147 assistant (NC), a resident of Rukungiri District and native Runyankore/Rukiga and fluent English

148 speaker, conducted all interviews with AP present. AP was not involved in providing clinical

149 care. NC, a Ugandan community member not involved in clinical care, approached patients to

150 gauge interest in study participation, limiting pressure to participate. Interviews, including only

151 the participants and these 2 researchers, took place in a private room outside of the ED to ensure

152 confidentiality and lasted 15-60 minutes. Interviews were conducted in local dialects, English, or

153 a combination, based on participant preference. Interviews were audio recorded, transcribed

154 verbatim, and translated into English within one week of the interview by NC, then checked for 
medRxiv preprint doi: https://doi.org/10.1101/2021.09.30.21264131; this version posted October 2, 2021. The copyright holder for this preprint (which was not certified by peer review) is the author/funder, who has granted medRxiv a license to display the preprint in perpetuity.

It is made available under a CC-BY-NC-ND 4.0 International license .

155 accuracy by a second bilingual member of the GEC Research Team (KA). If there was a

156 discrepancy in translation/interpretation the audio recording was reviewed by NC and KA

157 together and discussed until consensus was reached. Due to the nature of the sample - patients

158 utilizing the ED - typically participants were not available on site when transcription and

159 translation were complete. The IRB limited collection of contact information to ensure privacy,

160 therefore transcripts were not returned to interviewees for review.

161 An interdisciplinary, multicultural data analysis team composed of ECPs, Ugandan

162 members of the GEC Research Team, and AP was assembled to reduce the possible bias of a

163 single investigator's interpretation and to enhance the cultural depth of the data analysis [18-21].

164 The Framework Method, a rigorous and transparent process that produces a clear audit trail of

165 each step of data analysis carried out by multidisciplinary research teams, was utilized [19,21].

166 As little is known about delays in accessing available EC, in 2017 when the study was

167 conducted, a grounded theory approach was taken. The data analysis team met weekly, utilizing

168 the Framework Method to inductively identify:

169

- Concepts of delay present in multiple de-identified interviews (subthemes)

- Quotes depicting the subthemes

- Quotes depicting interesting outliers

172

After the first 25 interviews were conducted and analyzed, the data analysis team

173 identified that no additional large-scale concepts of delay were emerging. The team convened to

174 review subthemes across these first 25 interviews simultaneously and organize them, yielding the

1754 themes described in Results. These themes and subthemes constituted a codebook, included as

176 Appendix S2, facilitating coding of an additional 25 interviews completed to capture a broader

177 sample of demographic groups and chief complaints across both dry and rainy seasons, given 
medRxiv preprint doi: https://doi.org/10.1101/2021.09.30.21264131; this version posted October 2, 2021. The copyright holder for this preprint (which was not certified by peer review) is the author/funder, who has granted medRxiv a license to display the preprint in perpetuity.

It is made available under a CC-BY-NC-ND 4.0 International license.

178 differences in EC accessibility and subsistence agriculture activities. Data saturation was

179 determined when interviews failed to demonstrate additional themes related to treatment delay.

180 AP and NC then coded the identified themes, subthemes, and quotes in the transcripts using QSR

181 International's NVivo software, version 10, which was also used to analyze themes of delay by

182 patient and interviewee demographics. The Consolidated Criteria for Reporting Qualitative

183 Research (COREQ) was utilized to ensure comprehensive reporting [22].

\section{Results}

\section{Demographics}

186 The 50 ED patients for whom care was sought (13 of whom were interviewed directly)

187 had a mean age of 33 years. Patients had an approximately even distribution of gender, as well as

188 occupation (none, subsistence farmers and small business owner). Demographics and CCs for the

189 ED patients are illustrated in Table 1. A full list of CCs is included as Appendix S3. Fifty

190 interviews were completed, 37 with caregivers of ED patients and 13 with the ED patients

191 themselves. Interviewees had a mean age of 38 years, and the majority were women, worked as

192 subsistence farmers, and had received primary education. The demographics of interview

193 participants are presented in Table 2.

194 Table 1. Patients' Demographic Data and CC

Gender, no. (\%)
Male: 27 (54)

Female: 23 (46) 
medRxiv preprint doi: https://doi.org/10.1101/2021.09.30.21264131; this version posted October 2, 2021. The copyright holder for this preprint (which was not certified by peer review) is the author/funder, who has granted medRxiv a license to display the preprint in perpetuity.

It is made available under a CC-BY-NC-ND 4.0 International license .

\begin{tabular}{|c|c|}
\hline $\begin{array}{l}\text { Age (years) } \\
\quad \text { Intervals, no. (\%) }\end{array}$ & $\begin{array}{l}\text { Mean: } 33.2 \\
<1: 5(10) \\
1-4: 5(10) \\
5-17: 7(14) \\
18-55: 22(44) \\
>55: 11(22)\end{array}$ \\
\hline Occupations (Common), no. (\%) & $\begin{array}{l}\text { None: } 12(30) \\
\text { Subsistence farmer: } 16(32) \\
\text { Employed or business owner: } 13 \text { (26) }\end{array}$ \\
\hline Highest level of education & $\begin{array}{l}\text { Median: Primary }(\mathrm{n}=20 ; 40 \%) \\
\text { Range: None-University }\end{array}$ \\
\hline \multicolumn{2}{|c|}{$\underline{\mathrm{CC} \text { by body system and/or mechanism of injury, no. }(\%)^{*}}$} \\
\hline Medical illness: 38 (76) & Injury: 12 (24) \\
\hline Gastrointestinal/genitourinary: 12 (32) & Blunt trauma/fall: 5 (42) \\
\hline Other medical complaints: 10 (26) & Burn: 3 (25) \\
\hline Cardiopulmonary: 9 (24) & Road traffic accident: 3 (25) \\
\hline Neurologic: 7 (18) & Bite: $1(8)$ \\
\hline${ }^{*}$ See S3 for full list of CCs & \\
\hline
\end{tabular}

Table 2. Interview Participants' Demographic Data

\begin{tabular}{|ll|}
\hline Relationship to patient, no. $(\%)$ & $\begin{array}{l}\text { Parent: } 19(38) \\
\text { Self: } 13(26)^{*} \\
\text { Adult Child: } 9(18) \\
\text { Other family member: } 9(18)^{* *}\end{array}$ \\
Gender, no. $(\%)$ & $\begin{array}{l}\text { Female: } 36(72) \\
\text { Male: } 14(28)\end{array}$ \\
Age (years) & Mean: 38.1 \\
& Range: $20-82$
\end{tabular}


medRxiv preprint doi: https://doi.org/10.1101/2021.09.30.21264131; this version posted October 2, 2021. The copyright holder for this preprint (which was not certified by peer review) is the author/funder, who has granted medRxiv a license to display the preprint in perpetuity.

It is made available under a CC-BY-NC-ND 4.0 International license .

\begin{tabular}{|c|c|}
\hline Occupation, no. (\%) & $\begin{array}{l}\text { Subsistence farmer: } 33(66) \\
\text { Employed or business owner: } 14 \text { (28) } \\
\text { Student: } 3(6)\end{array}$ \\
\hline Highest level of education & $\begin{array}{l}\text { Median: Primary }(\mathrm{n}=32 ; 64 \%) \\
\text { Range: None-University }\end{array}$ \\
\hline
\end{tabular}

\section{Delay in ED Presentation}

All patients included in the study reported the acute onset of new symptoms or acute worsening of previously recognized symptoms leading to ED presentation. Delays were quantified as the duration of the patient's $\mathrm{CC}$ and the time from recognition of a severe condition necessitating EC (by the patient or their caregiver) to presentation at the ED. Both are presented in Table 3. The most notable trend related to treatment delay at the ED was history of chronic disease. ED patients with acute presentations and history of underlying chronic conditions experienced substantially longer delays in reaching the ED than otherwise healthy patients. Among chronically ill patients, recognition of acute symptoms needing EC ranged from 12 hours

$207-14$ days prior to arriving at the ED, with an average of 6 days. For all patients included in the 208 study the mean duration from recognition of symptoms necessitating EC to presentation at the 209 ED as 1 day. Patients with chronic disease and their caregivers reported challenges to decision210 making including perceptions that:

211 - acute decompensation of chronic disease may be self-limited decompensation

- the incurable nature of the disease meant acute stabilization and treatment of 
medRxiv preprint doi: https://doi.org/10.1101/2021.09.30.21264131; this version posted October 2, 2021. The copyright holder for this preprint (which was not certified by peer review) is the author/funder, who has granted medRxiv a license to display the preprint in perpetuity.

It is made available under a CC-BY-NC-ND 4.0 International license .

216 No other major trends in length of delay were identified based on patient demographics, or

217 medical illness vs injury.

218 Table 3. Patients' Delays in ED Presentation

\begin{tabular}{|c|c|c|c|c|}
\hline & $\underline{\text { All patients }}$ & Medical Illness & $\begin{array}{l}\text { History of } \\
\text { Chronic Disease }\end{array}$ & Injury \\
\hline \multirow{2}{*}{ Duration of CC } & Median: $5.5 \mathrm{~d}$ & Median: $7 \mathrm{~d}$ & Median: $112 \mathrm{~d}$ & Median: $2 \mathrm{~d}$ \\
\hline & Range: $12 \mathrm{~h}-3 \mathrm{y}$ & Range: $1 \mathrm{~d}-3 \mathrm{y}$ & Range: 7 d-3 y & Range: $12 \mathrm{~h}-30 \mathrm{~d}$ \\
\hline$\underline{\text { Time from }}$ & Median: $1 \mathrm{~d}$ & Median: $1 \mathrm{~d}$ & Median: $6 \mathrm{~d}$ & Median: $1.5 \mathrm{~d}$ \\
\hline$\frac{\frac{\text { recognition of }}{\text { need for EC to }}}{\text { ED presentation }}$ & Range: $2 \mathrm{~h}-17 \mathrm{~d}$ & Range: $<1 \mathrm{~h}-17 \mathrm{~d}$ & Range: $12 \mathrm{~h}-14 \mathrm{~d}$ & Range: $<1 \mathrm{~h}-7 \mathrm{~d}$ \\
\hline
\end{tabular}

\section{Themes in Delay}

221 Cultural Factors and Limited Knowledge of Emergency Signs and Initial Actions 222 to Take

223 Approximately half of study participants reported some specific symptom, such as

224 confusion or malaise, as a "danger sign" and increasing symptom severity as a primary rationale

225 for their decision to seek health care. Participants also reported that they did not consider

226 utilizing EC until they feared death was imminent.

227 On Saturday night around 2:00 AM the symptoms became very severe. I couldn't

228 breathe well; I didn't sleep, and I was like "I am going to die here" ... I said, "let

229 me call a Boda Boda [motorcycle taxi] to bring me so that I die [at] the hospital."

230 It is from then that I decided to come to Nyakibale [Hospital].

231 -30-39-year-old (yo) patient seeking care 
medRxiv preprint doi: https://doi.org/10.1101/2021.09.30.21264131; this version posted October 2, 2021. The copyright holder for this preprint (which was not certified by peer review) is the author/funder, who has granted medRxiv a license to display the preprint in perpetuity.

It is made available under a CC-BY-NC-ND 4.0 International license .

I made the decision after she had developed severe diarrhea, vomiting, and wasting, so it is (at) that point that I decided to bring her here for care, otherwise she would have died by now. Because she could not even eat or turn in bed...we thought she was going to die.

239 because of concern that they might have a "cultural illnesses" requiring treatment by a traditional

240 practitioner or priest. Cultural illnesses are thought to be caused or exacerbated by factors

241 allopathic medicine cannot treat. In these cases, the ED is utilized only when traditional

242 treatment is thought to have been ineffective, or when traditional causes of the ailment have been

243 sufficiently treated, enabling allopathic medicine to be effective. This approach was often

244 advised by elders in the family or community.

245 There are [cultural illnesses] that attacked the patient, [which] came from my

246 husband's family. We first thought that she was suffering from cultural illness.

247 Therefore, we had to first try treating with traditional herbs and then [go] to the

$248 \quad$ clinic.

$249 \quad-20-29 y o$ parent seeking care for $<5$ yo child

250 The majority of study participants noted that they received advice before making the

251 decision to seek EC. Most were advised to go directly to the ED, while some were advised to

252 treat the underlying cultural disease before seeking allopathic care. Some participants noted that

253 they did not tell ED staff about seeking traditional treatment for fear the staff might scold them

254 for delaying seeking EC. 
medRxiv preprint doi: https://doi.org/10.1101/2021.09.30.21264131; this version posted October 2, 2021. The copyright holder for this preprint (which was not certified by peer review) is the author/funder, who has granted medRxiv a license to display the preprint in perpetuity.

It is made available under a CC-BY-NC-ND 4.0 International license .

255 Use of Local Facilities for Stabilization and Advice Despite Perception of

256 Inadequate Services

257 Over three-quarters of participants reported consulting a nearby allopathic or traditional

258 medical care practitioner before presenting at the ED; approximately half described visiting

259 multiple health care facilities and/or practitioners before ED presentation. Participants reported

260 that obtaining care from multiple facilities is a common practice. Most providers utilized were

261 accessible by walking or bicycling. These nearby practitioners were often consulted to assess the

262 seriousness of the ailment and/or as an initial step in managing symptoms while gathering funds

263 to cover the costs of higher-level care.

264 In some cases, participants chose to wait until this initial care was deemed ineffective

265 before considering other options. However, most perceived the ED to offer superior care. Private

266 clinics were reported by participants to lack necessary medication and materials, communicate

267 poorly about the patient's condition and treatment, and generally provide inadequate care at high

268 cost. Participants reported spending an average of $\$ 8$ on care - a large sum in rural Uganda-

269 before presenting at the ED.

270

It was lack of money, if you don't have money then you stay home or go to private clinics because you calculate the money for transport to getting here (the ED) ....

275 they were unable to provide adequate care. Despite this, once a referral was made, participants

276 often had to search for funds or gather supplies before seeking higher-level care.

277 ... First, I sought health care in many private clinics...[Then], I decided to take

278 the patient to [an outside] hospital and reaching there, they referred us here... I 
medRxiv preprint doi: https://doi.org/10.1101/2021.09.30.21264131; this version posted October 2, 2021. The copyright holder for this preprint (which was not certified by peer review) is the author/funder, who has granted medRxiv a license to display the preprint in perpetuity.

It is made available under a CC-BY-NC-ND 4.0 International license .

took the patient back home [for 2 days] so that I could prepare and come here.... I wanted to prepare what we were to use here [at the hospital], like food, and other things. -20-29yo parent seeking care for <5yo child

\section{Lack of Resources to Cover the Direct, Indirect, and Opportunity Costs of EC}

While most participants understood that payment was not required before ED care, they perceptions regarding how much cash on hand participants felt they needed going to the ED. Speculations ranged broadly $(\$ 10-\$ 150)$ and seemed unrelated to severity of patient complaint. Whatever the dollar amount mentioned, participants felt that receiving care at Karoli Lwanga Hospital would be "somewhat" to "extremely" unaffordable. In many cases it was not the direct

291 cost of the hospital that caused delays once a health problem was deemed severe, but indirect costs, including the expense of traveling to the hospital and paying for nonmedical supplies that would be needed by the patient and caregiver during their stay. measurement from a prior study [23]) at a mean cost of \$6. Half reported that finding funds to

297 pay for transportation was the greatest factor associated with delay. Once they obtained funding

298 for transport, participants presented to the ED for evaluation, stabilization, and treatment and 299 continued to search for funds to pay their hospital bill after obtaining EC. 
medRxiv preprint doi: https://doi.org/10.1101/2021.09.30.21264131; this version posted October 2, 2021. The copyright holder for this preprint (which was not certified by peer review) is the author/funder, who has granted medRxiv a license to display the preprint in perpetuity.

It is made available under a CC-BY-NC-ND 4.0 International license .

for money later but let us first take her to the hospital."

307 Extended family and neighbors were often asked to assist in supervising children, tending gardens and livestock, and ensuring the security of properties. they will prepare food for themselves. Their grandmother (lives) at a distance but sometimes she comes and helps...You can't leave the home alone. Also, farming being our business and it being a season of planting is hard." - 20-29yo parent seeking care for 5-9yo child

\section{Inadequate Transportation Options, Especially at Night and in Inclement 323 Weather} so sick I couldn't stand. Actually, this caused a long delay, for 4 days, because I was thinking about who will take care of my farms. I had even reached the point of refusing to be taken for medical care. I was worried about what I will feed my children after being discharged from the hospital, because I was leaving all my harvests in the farm... This disturbed [me] a lot. -40-49yo patient seeking care

Transportation is a common source of delay for several reasons. Participants reported 
medRxiv preprint doi: https://doi.org/10.1101/2021.09.30.21264131; this version posted October 2, 2021. The copyright holder for this preprint (which was not certified by peer review) is the author/funder, who has granted medRxiv a license to display the preprint in perpetuity.

It is made available under a CC-BY-NC-ND 4.0 International license .

325 difficulty reaching a main road to access vehicles for hire. Once at the road, many reported

326 difficulties locating a car or truck adequate for transporting patients with severe illness.

327 Inclement weather, especially rain, further constrained participants' transport options. During

328 monsoon season, motorcycle taxis — the most common form of transportation-were often

329 unusable as dirt roads turned to mud following torrential rains.

330 decided to come.

\section{Discussion}

344 Extensive literature is available on factors influencing illness-specific (eg, HIV, malaria)

345 and demographic-specific (eg, pediatrics, maternity) health care seeking in Uganda [24-31].

346 However, only sparse research exists on challenges facing patients experiencing acute illness or 
medRxiv preprint doi: https://doi.org/10.1101/2021.09.30.21264131; this version posted October 2, 2021. The copyright holder for this preprint (which was not certified by peer review) is the author/funder, who has granted medRxiv a license to display the preprint in perpetuity.

It is made available under a CC-BY-NC-ND 4.0 International license .

347 injury, and little of this pertains to when formal EC is available in a rural area.

348 This study presents data on the first stage of multistage formative research centered on

349 gaining insights into factors influencing treatment delay to EC by rural community members

350 [32,33]. A forthcoming study will explore possible interventions to increase timely EC access.

351 This study identified four broad areas where interventions are warranted. It was informed by the

352 Three Delays Model initially developed for obstetric emergencies [17] and applied more broadly

353 to EC by Calvello et al [34] and Broccoli et al [35]. In the Three Delays Model [17]:

354 1. The first delay is the decision to seek care, including factors such as:

355 - Availability of decision makers

- Cultural perceptions that predispose community members to visit a traditional healer and/or self-treatment prior to seeking allopathic care

- Distance to EC

- Costs of accessing care

- Availability of a caregiver to accompany the patient

- Perceptions of the etiology and severity of an illness or injury, and the quality of care available

2. The second delay includes challenges in identifying and reaching a health facility, such as:

- Distance to EC

- Availability and cost of transport

- Availability of a caregiver to accompany the patient facility, including factors such as: 
medRxiv preprint doi: https://doi.org/10.1101/2021.09.30.21264131; this version posted October 2, 2021. The copyright holder for this preprint (which was not certified by peer review) is the author/funder, who has granted medRxiv a license to display the preprint in perpetuity.

It is made available under a CC-BY-NC-ND 4.0 International license .

- Appropriateness and quality of care offered

- Resources at hand

- Competent referral, as needed

We studied the first 2 delays in depth. Although participants alluded to the third delay,

374 we did not explicitly include this delay in the study aims or directly investigate the quality of

375 care or timeliness of referrals offered by other facilities. The interrelated nature of delays in the

376 Three Delays Model and our own themes of delay are illustrated in Fig 1.

377 Fig 1. Themes of Delay of this Study Correlated with the Three Delays Model

\section{The Three-Delays Model in EC as Proposed by Calvello et al.}

Factors affecting service utilization and outcomes

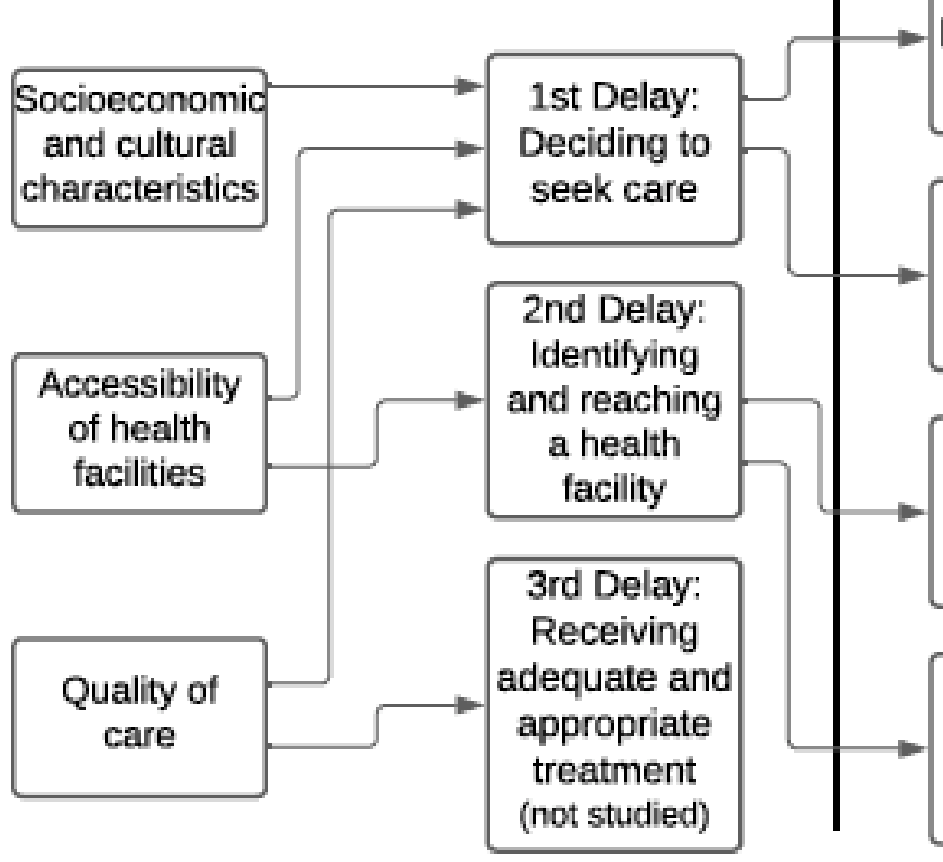

Themes Identified in this Study

Cultural factors and limited knowledge of emergency signs and initial actions to take

Use of local facilities for stabilization and advice despite perception of inadequate services

Lack of resources to cover the direct, indirect, and opportunity costs of EC Inadequate transportation options, especially at night and in inclement weather

379 Abbreviations: EC, emergency care.

380 Our results generally support the applicability of the three delays model to accessing EC

381 at the community level. While we did not research delay in receiving adequate care at health 
medRxiv preprint doi: https://doi.org/10.1101/2021.09.30.21264131; this version posted October 2, 2021. The copyright holder for this preprint (which was not certified by peer review) is the author/funder, who has granted medRxiv a license to display the preprint in perpetuity.

It is made available under a CC-BY-NC-ND 4.0 International license .

382 facilities directly from interview participants' perceptions of delay in obtaining adequate

383 treatment and/or referral at outlying facilities it can likely be implied that this delay is equally

384 relevant, however further research is needed.

385 In this study, we found that, on average, 4 days elapsed between onset of the $\mathrm{CC}$ and the

386 illness/injury being recognized as needing emergency treatment by the patient or caregiver.

387 Another day passed between recognition of the need for EC and ED presentation.

388 The First Delay - Decision to Seek Care

389 Cultural Factors and Limited Knowledge of Emergency Signs and Initial

390 Actions to Take

391 Delays often occurred in part because of a failure to recognize danger signs soon enough.

392 Many participants traveled to the ED only when the patient's condition increased in severity to

393 the point it was considered "life-threatening." Lack of knowledge or confidence regarding the

394 danger signs heralding medical emergencies is consistent with earlier studies from rural areas of

395 SSA [30,35-37], as well as the findings of a recent systematic review of barriers to seeking EC

396 in LMICs globally [38].

397 Home care (dietary change, bathing, bleeding control, and use of medicines purchased at

398 informal pharmacies) is well documented in Ugandan studies of pediatric fever [27] and obstetric

399 emergencies [37]. In this study, we found that once severe illness was recognized, few

400 participants continued home care except as a stopgap measure while gathering resources for

401 consultation with an allopathic or traditional practitioner. In the case of injury, our findings are

402 consistent with other East African studies reporting that few injury victims receive care at the

403 scene of accidents or en route to a health facility, despite lengthy transports [39-41]. In keeping 
medRxiv preprint doi: https://doi.org/10.1101/2021.09.30.21264131; this version posted October 2, 2021. The copyright holder for this preprint (which was not certified by peer review) is the author/funder, who has granted medRxiv a license to display the preprint in perpetuity.

It is made available under a CC-BY-NC-ND 4.0 International license .

404 with prior studies, participants reported lack of first aid skills and supplies and expressed a desire

405 for training $[35,36,42,43]$.

406 In the case of culturally salient folk illnesses, it is deemed pragmatic to seek traditional

407 medicine before allopathic treatment. Traditional medicine is thought to improve efficacy of

408 allopathic medicine, by removing cultural factors. Thus, not trying traditional medicine first

409 might lead to a waste of resources, if only allopathic treatment is used and is ineffective. When

410 the patient recovers after traditional treatment, before or in concert with allopathic treatment,

411 dual causality of the illness is presumed [44,45].

412 Based on this data we will conduct community based research which:

413 - Investigates how best to educate community members to recognize the danger signs of

$414 \quad$ acute illness/injury and administer basic first aid.

415 - Assesses self-care practices.

416 - Seeks to better understand existing traditional medicine and explores the possibility of

417 establishing collaborative relationships with traditional healers as a means of promoting

418 rapid referral for EC.

419 Use of Local Facilities for Stabilization and Advice Despite Perception of

420 Inadequate Services

421 Before presenting to the ED, most study participants sought care from at least one local

422 practitioner offering either traditional or allopathic treatment. Notably, we found that,

423 participants did not choose to go to local allopathic clinics because they had confidence in, or

424 good rapport with, local practitioners. Rather, they resorted to these clinics because of their

425 accessibility and the perception that obtaining care at the ED would prove costly, even if funds

426 were not demanded before treatment. 
medRxiv preprint doi: https://doi.org/10.1101/2021.09.30.21264131; this version posted October 2, 2021. The copyright holder for this preprint (which was not certified by peer review) is the author/funder, who has granted medRxiv a license to display the preprint in perpetuity.

It is made available under a CC-BY-NC-ND 4.0 International license .

Similar to the findings of other studies conducted in Uganda, the general impression of

428 participants was that government health stations and private clinics offer low-quality care and are

429 best consulted as a stopgap measure until funds can be secured to travel to a hospital if the

430 patient's condition does not improve [24,27,28,30]. Interim treatment measures to allow time to

431 monitor symptoms, identify possible etiologies, and select treatment options have also been

432 documented in other settings [46].

433 Our study suggests that local clinics are resorted to for practical reasons, mainly as a

434 stopgap measure while gathering funds needed for transportation. This suggests a need for both

435 emergency transportation and referral systems in which local practitioners-both allopathic and

436 traditional - feel they are members of a community of health care practice [32]. As members of

437 such a community of practice, practitioners will need to receive training in danger signs

438 warranting immediate referral to a EC.

439 The Second Delay - Reaching Care

440 Lack of Resources to Cover the Direct, Indirect, and Opportunity Costs of EC

441 Cost is a major factor contributing to delays in seeking health care in rural Uganda and

442 similar settings $[30,35,36,41,42,47,48]$. Three distinct types of cost need to be recognized when

443 considering delays in obtaining EC: direct fees for health care services, indirect costs (eg,

444 transport, food, lodging, and medical supplies/medications required for the accompanying

445 caregiver), and opportunity costs of seeking care. Opportunity costs include both the financial

446 impact of health care seeking on income-generating activities and loss of time to perform

447 essential household activities such as childcare [49]. Interviewees tended to focus on indirect

448 and opportunity costs. The most prevalent indirect costs discussed were transport and the need 
medRxiv preprint doi: https://doi.org/10.1101/2021.09.30.21264131; this version posted October 2, 2021. The copyright holder for this preprint (which was not certified by peer review) is the author/funder, who has granted medRxiv a license to display the preprint in perpetuity.

It is made available under a CC-BY-NC-ND 4.0 International license .

449 for money to cover necessities like food while at the hospital. Caregivers repeatedly mentioned

450 opportunity costs of accompanying patients to the hospital. Patient caregivers needed to find

451 substitute labor to attend to essential household tasks in their absence. Concern about the status

452 of one's children and farm were reported by nearly all participants interviewed. Asking kin or

453 neighbors to watch children or farms has been noted to strain social relations, especially if

454 assistance is needed during peak agricultural seasons [50].

455 Searching for a loan with little disposable income was a common source of delay and one

456 that has been well described by several other studies in SSA $[37,51,52]$. While community

457 saving and lending programs do exist in the Rukungiri District, they are not typically structured

458 to provide emergency funds. Participants spoke of the difficulties entailed in borrowing money,

459 especially between harvest seasons, as most are subsistence farmers. This elucidates the need for

460 future formative research on implementation of EC specific loan schemes that build upon

461 already-thriving rotating credit and microfinance programs within the community.

462 Inadequate Transportation Options, Especially at Night and in Inclement

463 Weather

464 Difficulties obtaining transportation to the hospital was a theme in nearly all interviews.

465 Interviewees often did not have cash on hand for transport, which is generally paid in advance

466 and not available on credit. Once participants were finally able to gather funds, finding transport

467 was often a challenge. The dangers of poorly maintained roads worsened the challenge,

468 especially at night and during inclement weather. Many participants were left with no other

469 option but to use less-safe forms of transport like motorcycle taxis. Multiple studies on health

470 care seeking in Uganda and other countries in SSA have also identified transportation as a key 
medRxiv preprint doi: https://doi.org/10.1101/2021.09.30.21264131; this version posted October 2, 2021. The copyright holder for this preprint (which was not certified by peer review) is the author/funder, who has granted medRxiv a license to display the preprint in perpetuity.

It is made available under a CC-BY-NC-ND 4.0 International license .

472 conducted at this study site found that the distance from the patient home to the ED significantly

473 impacted patient outcomes. In this study, compared to patients living $<5 \mathrm{~km}$ from the hospital,

474 patients living 5-10 km away had 1.7 times the rate of mortality at 3 days, and those living $>10$

$475 \mathrm{~km}$ away, 2.2 times [23].

476 This study indicates the need for an emergency transport system to be set up within the

477 hospital catchment area. Following the period of this study, Nyakibale Hospital has collaborated

478 with Humanitarian Aid for Uganda, a German nongovernmental organization, to set up an

479 ambulance system in the district. Currently, 2 ambulances are staffed by volunteer ECPs and

480 midwifes who carry an emergency phone. Their phone number has been widely distributed in the

481 community. To facilitate timely ED access, payment for ambulance service is not required at the

482 time of transport. Given that mobile phone service is rapidly increasing in rural Uganda, future

483 formative research will investigate whether arrangements might be made with vehicles for hire to 484 pick up patients for a set fee, if and when an ambulance service cannot be accessed.

\section{The Third Delay - Health Care Services}

Referral delay from local healthcare facilities was beyond the scope of this study and

487 will require a study of practitioners' recognition of danger signs, the quality of care available at 488 local clinics, and financial motivations for delaying a patient before referral. The collection of

489 such data in the future is needed to inform health service interventions which provide

490 bidirectional rewards for both local practitioners and the ED while promoting timely EC referral;

491 in order to be successful, local practitioners will need to gain status by facilitating timely

492 referrals. 
medRxiv preprint doi: https://doi.org/10.1101/2021.09.30.21264131; this version posted October 2, 2021. The copyright holder for this preprint (which was not certified by peer review) is the author/funder, who has granted medRxiv a license to display the preprint in perpetuity.

It is made available under a CC-BY-NC-ND 4.0 International license .

\section{Limitations}

Four limitations of this study may be noted. First, interviews were held at the ED. While

495 this allowed access to participants currently utilizing EC and likely reduced recall bias through

496 timely data collection, participants may have been uncomfortable sharing negative perceptions of

497 ED services while receiving treatment. Second, the study did not include patients who were

498 unable to present at the ED and therefore may not have identified additional barriers to EC

499 access and utilization by the most vulnerable people in the hospital's catchment area. We plan to

500 address this limitation in forthcoming research utilizing community-based focus groups. Third,

501 we did not study delayed referral to ED from local health facilities, nor the quality of care

502 offered at these facilities. Forth, this study was not designed to quantitatively assess household

503 level factors potentially influencing delay in presentation to the ED, such as, age, gender, birth

504 order, and household structure.

505 A final limitation of this study relates to sampling and the generalizability of the data

506 collected. The objective of this qualitative study was to identify the range of factors that affect

507 care seeking behavior at a relatively newly established ED. A purposeful sample was employed

508 toward this end. As such, this data is not generalizable to other EDs although it is reasonable to

509 hypothesize that similar factors leading to treatment delay may apply.

\section{Conclusions}

511 EC can substantially reduce preventable complications and mortality in LMICs when the

512 signs of acute illness and injury are recognized early, referral networks are established, and

513 community members view EDs as accessible and affordable. Setting up EDs and training staff in 
medRxiv preprint doi: https://doi.org/10.1101/2021.09.30.21264131; this version posted October 2, 2021. The copyright holder for this preprint (which was not certified by peer review) is the author/funder, who has granted medRxiv a license to display the preprint in perpetuity.

It is made available under a CC-BY-NC-ND 4.0 International license .

514 LMICs is only the first step in ensuring that availability of EC services . In Uganda, a well-

515 functioning ED was established, and a health care team trained; however, patient presentations to

516 the ED are often delayed, reducing its potential benefits. This qualitative research study

517 identified major factors contributing to delays in visiting the ED. It corroborates and builds on

518 the findings of other non-EC related health service delivery studies utilizing the Three Delays

519 Model and recommends the need for the next phase of formative research to identify and weigh

520 the advantages and disadvantages of various community-based EC educational, financial,

521 transport, and referral network interventions.

\section{Acknowledgments}

523 The authors sincerely thank the Global Emergency Care Collaborative Investigators Mark

524 Bisanzo, Heather Hammerstedt, Stacey Chamberlain and Bradley Dreifuss for their work in

525 developing the EC and research infrastructure that made this study possible. Additionally, we

526 would like to thank the GEC Research Team Members Charles Ndyamwijuka, Adrine Kusasira

527 and Nelly Mbabazi for their tireless work on the research tool, interviews and data analysis,

528 Hilary Kizza, GEC Program Coordinator, for his administrative support, Joseph Kalanzi and

529 Edgar Mugema Mulogo for their assistance conceptualizing this project in the Ugandan context,

530 and Deborah Stein for providing language editing of the manuscript. The Hospital Management

531 Team at Karoli Lwanga Hospital also provided invaluable support for this study and the ECP

532 program. Finally, we would like to thank the Emergency Care Practitioners for their assistance

533 with patient recruitment and data analysis, as well the critical EC they provide 
medRxiv preprint doi: https://doi.org/10.1101/2021.09.30.21264131; this version posted October 2, 2021. The copyright holder for this preprint (which was not certified by peer review) is the author/funder, who has granted medRxiv a license to display the preprint in perpetuity.

\section{References}

1. Hsia RY, Thind A, Zakariah A, Hicks ER, Mock C. Prehospital and Emergency Care: Updates from the Disease Control Priorities, Version 3. World J Surg. 2015 Sep $1 ; 39(9): 2161-7$.

2. SIXTIETH WORLD HEALTH ASSEMBLY. WHA60.22: Health systems: emergency-care systems [Internet]. 2007 [cited 2020 Dec 20]. Available from: https://apps.who.int/iris/bitstream/handle/10665/22596/A60_R22en.pdf?sequence $=1 \&$ is Allowed $=y$

3. WHA72 R. Resolution WHA72.16. Emergency care systems for universal health coverage: ensuring timely care for the acutely ill and injured. Seventysecond World Health Assem Geneva. 2019;28.

4. Lecky FE, Reynolds T, Otesile O, Hollis S, Turner J, Fuller G, et al. Harnessing interdisciplinary collaboration to improve emergency care in low- and middle-income countries (LMICs): results of research prioritisation setting exercise. BMC Emerg Med. 2020 Aug 31;20(1):68.

5. Hansoti B, Aluisio AR, Barry MA, Davey K, Lentz BA, Modi P, et al. Global Health and Emergency Care: Defining Clinical Research Priorities. Acad Emerg Med. 2017;24(6):74253.

6. RUKUNGIRI DISTRICT LOCAL GOVERNMENT. FIVE YEAR DISTRICT DEVELOPMENT PLAN II 2015/2016-2019/2020 [Internet]. 2015 [cited 2020 Dec 20]. Available from: http://npa.go.ug/wp-content/uploads/2017/05/FINAL-DDPII-Rukungiri2015-2020.pdf

7. Ugandan Bureau of Statistics. Western Region - Parish Level Profiles (Census 2014) [Internet]. [cited 2020 Dec 20]. Available from: https://www.ubos.org/explore-statistics/20/

8. O'Dea S. Mobile subscription penetration Uganda 2000-2019 [Internet]. Statista. [cited 2020 Dec 20]. Available from: https://www.statista.com/statistics/510637/mobile-cellularsubscriptions-per-100-inhabitants-in-uganda/

9. Kyomuhendo GB. Low Use of Rural Maternity Services in Uganda: Impact of Women's Status, Traditional Beliefs and Limited Resources. Reprod Health Matters. 2003;11(21):1626.

10. Nsungwa-Sabiiti J, Kallander K, Nsabagasani X, Namusisi K, Pariyo G, Johansson A, et al. Local fever illness classifications: implications for home management of malaria strategies. Trop Med Int Health. 2004;9(11):1191-9. 
medRxiv preprint doi: https://doi.org/10.1101/2021.09.30.21264131; this version posted October 2, 2021. The copyright holder for this preprint (which was not certified by peer review) is the author/funder, who has granted medRxiv a license to display the preprint in perpetuity. It is made available under a CC-BY-NC-ND 4.0 International license.

11. Kirimuhuzya C, Waako P, Joloba M, Odyek O. The anti-mycobacterial activity of Lantana camara a plant traditionally used to treat symptoms of tuberculosis in South-western Uganda. Afr Health Sci. 2009;9(1):40-5.

12. Uganda One Health Strategic Plan 2018-2022 [Internet]. Ministry of Health | Government of Uganda. [cited 2020 Dec 20]. Available from: https://www.health.go.ug/cause/uganda-onehealth-strategic-plan-2018-2022/

13. Ministry of Health. HEALTH SECTOR STRATEGIC \& INVESTMENT PLAN 2010/11 2014/15 [Internet]. [cited 2020 Dec 20]. Available from: https://www.health.go.ug/docs/HSSIP10.pdf

14. Kiguli J, Ekirapa-Kiracho E, Okui O, Mutebi A, Macgregor H, Pariyo GW. Increasing access to quality health care for the poor: Community perceptions on quality care in Uganda. Patient Prefer Adherence. 2009/11/26 ed. 2009;3:77-85.

15. Hammerstedt H, Maling S, Kasyaba R, Dreifuss B, Chamberlain S, Nelson S, et al. Addressing World Health Assembly Resolution 60.22: A Pilot Project to Create Access to Acute Care Services in Uganda. Ann Emerg Med. 2014 Nov 1;64(5):461-8.

16. Patton MQ. Qualitative research. Encycl Stat Behav Sci. 2005;

17. Thaddeus S, Maine D. Too far to walk: Maternal mortality in context. Soc Sci Med. 1994;38(8):1091-110.

18. Teufel-Shone NI, Williams S. Focus Groups in Small Communities. Prev Chronic Dis [Internet]. 2010 Apr 15 [cited 2020 Dec 24];7(3). Available from: https://www.ncbi.nlm.nih.gov/pmc/articles/PMC2879999/

19. Gale NK, Heath G, Cameron E, Rashid S, Redwood S. Using the framework method for the analysis of qualitative data in multi-disciplinary health research. BMC Med Res Methodol. 2013 Sep 18;13(1):117.

20. Patton MQ. Enhancing the quality and credibility of qualitative analysis. Health Serv Res. 1999;34(5 Pt 2):1189.

21. Ward DJ, Furber C, Tierney S, Swallow V. Using Framework Analysis in nursing research: a worked example. J Adv Nurs. 2013;69(11):2423-31.

22. Tong A, Sainsbury P, Craig J. Consolidated criteria for reporting qualitative research (COREQ): a 32-item checklist for interviews and focus groups. Int J Qual Health Care. 2007 Dec 1;19(6):349-57.

23. Tiemeier K, Bisanzo M, Dreifuss BA, Ward KC. The effect of geography and demography on outcomes of emergency department patients in rural Uganda. Ann Glob Health. 2014;80(3). 
medRxiv preprint doi: https://doi.org/10.1101/2021.09.30.21264131; this version posted October 2, 2021. The copyright holder for this preprint (which was not certified by peer review) is the author/funder, who has granted medRxiv a license to display the preprint in perpetuity. It is made available under a CC-BY-NC-ND 4.0 International license.

24. Hildenwall H, Tomson G, Kaija J, Pariyo G, Peterson S. "I never had the money for blood testing" - Caretakers' experiences of care-seeking for fatal childhood fevers in rural Uganda - a mixed methods study. BMC Int Health Hum Rights. 2008 Dec 2;8(1):12.

25. Hildenwall H, Nantanda R, Tumwine JK, Petzold M, Pariyo G, Tomson G, et al. Careseeking in the development of severe community acquired pneumonia in Ugandan children. Ann Trop Paediatr. 2009 Dec;29(4):281-9.

26. Kallander K, Hildenwall H, Waiswa P, Galiwango E, Peterson S, Pariyo G. Delayed care seeking for fatal pneumonia in children aged under five years in Uganda: a case-series study. In: Bull World Health Organ. Switzerland; 2008. p. 332-8.

27. Rutebemberwa E, Kallander K, Tomson G, Peterson S, Pariyo G. Determinants of delay in care-seeking for febrile children in eastern Uganda. Trop Med Int Health. 2009;14(4):472-9.

28. Rutebemberwa E, Pariyo G, Peterson S, Tomson G, Kallander K. Utilization of public or private health care providers by febrile children after user fee removal in Uganda. Malar J. 2009;8:45.

29. Kaye DK, Kakaire O, Nakimuli A, Osinde MO, Mbalinda SN, Kakande N. Lived experiences of women who developed uterine rupture following severe obstructed labor in Mulago hospital, Uganda. Reprod Health. 2014;11:31.

30. Sundararajan R, Mwanga-Amumpaire J, Adrama H, Tumuhairwe J, Mbabazi S, Mworozi K, et al. Sociocultural and structural factors contributing to delays in treatment for children with severe malaria: a qualitative study in southwestern Uganda. Am J Trop Med Hyg. 2015;92(5):933-40.

31. Kabakyenga JK, Östergren P-O, Turyakira E, Pettersson KO. Knowledge of obstetric danger signs and birth preparedness practices among women in rural Uganda. Reprod Health. 2011;8(1):33.

32. Awah PK, Boock AU, Mou F, Koin JT, Anye EM, Noumen D, et al. Developing a Buruli ulcer community of practice in Bankim, Cameroon: A model for Buruli ulcer outreach in Africa. PLoS Negl Trop Dis. 2018;12(3):e0006238.

33. Tolley EE, Ulin PR, Mack N, Robinson ET, Succop SM. Qualitative methods in public health: a field guide for applied research. John Wiley \& Sons; 2016.

34. Calvello EJ, Skog AP, Tenner AG, Wallis LA. Applying the lessons of maternal mortality reduction to global emergency health. Bull World Health Organ. 2015;93:417-23.

35. Broccoli MC, Cunningham C, Twomey M, Wallis LA. Community-based perceptions of emergency care in Zambian communities lacking formalised emergency medicine systems. Emerg Med J. 2016;33(12):870-5. 
medRxiv preprint doi: https://doi.org/10.1101/2021.09.30.21264131; this version posted October 2, 2021. The copyright holder for this preprint (which was not certified by peer review) is the author/funder, who has granted medRxiv a license to display the preprint in perpetuity. It is made available under a CC-BY-NC-ND 4.0 International license .

36. Broccoli MC, Calvello EJ, Skog AP, Wachira B, Wallis LA. Perceptions of emergency care in Kenyan communities lacking access to formalised emergency medical systems: a qualitative study. BMJ Open. 2015;5(11).

37. Nansubuga E, Ayiga N. Male involvement in utilization of emergency obstetric care and averting of deaths for maternal near misses in Rakai district in Central Uganda. Afr Popul Stud. 2015;29(2).

38. Kironji AG, Hodkinson P, De Ramirez SS, Anest T, Wallis L, Razzak J, et al. Identifying barriers for out of hospital emergency care in low and low-middle income countries: a systematic review. BMC Health Serv Res. 2018;18(1):291.

39. Rotich C, Staton CL, Mvungi M. 26 Evaluating access to prehospital care for traumatic brain injury patients in a resource limited setting: focus on prehospital transport. BMJ Publishing Group Ltd; 2015.

40. de Ramirez SS, Carle S, Arii M, Okongo M, Moresky R, Sachs SE, et al. 308 Trauma as the Neglected Emergency After Emergency Medical Services Systems Introduction: Lessons Learned From Rural Uganda. Ann Emerg Med. 2011;4(58):S281.

41. Macharia WM, Njeru EK, Muli-Musiime F, Nantulya V. Severe road traffic injuries in Kenya, quality of care and access. Afr Health Sci. 2009;9(2).

42. Kuzma K, Lim AG, Kepha B, Nalitolela NE, Reynolds TA. The Tanzanian trauma patients' prehospital experience: a qualitative interview-based study. BMJ Open. 2015;5(4):e006921.

43. Jayaraman S, Mabweijano JR, Lipnick MS, Caldwell N, Miyamoto J, Wangoda R, et al. Current patterns of prehospital trauma care in Kampala, Uganda and the feasibility of a layfirst-responder training program. World J Surg. 2009;33(12):2512-21.

44. Nichter M. Social Science Contributions to BU Focused Health Service Research in WestAfrica. In: Buruli Ulcer. Springer, Cham; 2019. p. 249-72.

45. Nichter M, Nichter M. Acute respiratory illness: popular health culture and mother's knowledge in the Philippines. Med Anthropol. 1993;15(4):353-75.

46. Ryan GW. What do sequential behavioral patterns suggest about the medical decisionmaking process?: modeling home case management of acute illnesses in a rural Cameroonian village. Soc Sci Med. 1998;46(2):209-25.

47. Wesson HK, Stevens KA, Bachani AM, Mogere S, Akungah D, Nyamari J, et al. Trauma systems in Kenya: a qualitative analysis at the district level. Qual Health Res. 2015;25(5):589-99.

48. Wen LS, Char DM. Existing infrastructure for the delivery of emergency care in postconflict Rwanda: an initial descriptive study. Afr J Emerg Med. 2011;1(2):57-61. 
medRxiv preprint doi: https://doi.org/10.1101/2021.09.30.21264131; this version posted October 2, 2021. The copyright holder for this preprint (which was not certified by peer review) is the author/funder, who has granted medRxiv a license to display the preprint in perpetuity. It is made available under a CC-BY-NC-ND 4.0 International license .

49. Kroeger A. Anthropological and socio-medical health care research in developing countries. Soc Sci Med. 1983;17(3):147-61.

50. Agbo IE, Johnson RC, Sopoh GE, Nichter M. The gendered impact of Buruli ulcer on the household production of health and social support networks: Why decentralization favors women. PLoS Negl Trop Dis. 2019;13(4):e0007317.

\section{4}

51. Kallander K, Tomson G, Nsabagasani X, Sabiiti JN, Pariyo G, Peterson S. Can community health workers and caretakers recognise pneumonia in children? Experiences from western Uganda. Trans R Soc Trop Med Hyg. 2006;100(10):956-63.

52. Peterson S, Nsungwa-Sabiiti J, Were W, Nsabagasani X, Magumba G, Nambooze J, et al. Coping with paediatric referral--Ugandan parents' experience. Lancet. 2004;363(9425):1955-6.

53. de Ramirez SS, Doll J, Carle S, Anest T, Arii M, Hsieh YH, et al. Emergency response in resource-poor settings: a review of a newly-implemented EMS system in rural Uganda. Prehosp Disaster Med. 2014;29(3):311-6. pathway of obstructed labour as perceived by communities in south-western Uganda: a grounded theory study. Glob Health Action [Internet]. 2011;4. Available from: http://dx.doi.org/10.3402/gha.v4i0.8529 